\title{
Pengaruh Pemberian Air Kelapa (Cocos nucifera L.) dan Atonik Terhadap Pertumbuhan Tanaman Cabai Merah Besar (Capsicum annuum L.)
}

\author{
Hasti Maulidya Fassya ${ }^{1}{ }^{*}$, Tundjung Tripeni Handayani ${ }^{2}$, Sri Wahyuningsih ${ }^{3}$, \\ Mahfut ${ }^{4}$
}

\author{
1,2,3,4 Program Studi Biologi, Jurusan Biologi, FMIPA, Universitas Lampung, Bandar Lampung, Email:

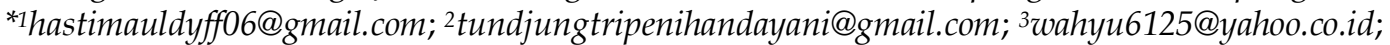 \\ ${ }^{4}$ mahfut.mipa@fmipa.unila.ac.id
}

\begin{abstract}
ABSTRAK
Cabai merah besar (Capsicum annuum L.) memiliki kandungan gizi yang cukup lengkap juga memiliki nilai ekonomis tinggi. Ketersediaan cabai merah besar dalam negeri masih rendah dibandingkan kebutuhan akan cabai yang tinggi, sehingga produksi perlu ditingkatkan. Peningkatan produksi bisa dilakukan dengan pemupukan menggunakan pupuk alami yaitu air kelapa (Cocos nucifera L.) dan pemberian Zat Pengatur Tumbuh (ZPT) yaitu atonik. Penelitian ini bertujuan untuk mengetahui pengaruh pemberian air kelapa dan atonik terhadap pertumbuhan cabai merah besar dan mengetahui konsentrasi air kelapa dan atonik yang paling efektif terhadap pertumbuhan tanaman cabai merah besar. Penelitian ini dilaksanakan pada pada bulan Oktober November 2019 di Laboratorium Botani, Jurusan Biologi, Fakultas Matematika dan Ilmu Pengetahuan, Universitas Lampung. Penelitian ini dilakukan menggunakan rancangan faktorial $2 \times 3$ yaitu menggunakan air kelapa muda (a) dengan 3 taraf konsentrasi yaitu $0 \% \mathrm{v} / \mathrm{v}(\mathrm{a} 1), 25 \% \mathrm{v} / \mathrm{v}$ (a2) dan 50\% v/v (a3) dan larutan atonik (b) dengan 2 taraf konsentrasi yaitu 0\% v/v (b1) dan 10\% $\mathrm{v} / \mathrm{v}\left(\mathrm{b}_{2}\right)$. Analisis data yaitu data dihomogenkan dahulu dengan uji Levene pada taraf nyata $5 \%$. Analisis data menggunakan analisis ragam (Analysis Of Variance) $a=5 \%$. Jika interaksi kedua faktor nyata maka dilanjutkan dengan penentuan simple effect air kelapa pada setiap taraf konsentrasi atonik dengan uji $\mathrm{F}$ pada taraf nyata $5 \%$. Hasil penelitian menunjukkan bahwa penambahan atonik dan air kelapa berpengaruh terhadap pertumbuhan tanaman cabai merah besar, dan konsentrasi yang paling efektif terhadap pertumbuhan cabai merah besar yaitu pada kombinasi antara air kelapa $0 \%+$ atonik $10 \%$.
\end{abstract}

Kata Kunci: air kelapa, atonik, cabai merah besar (Capsicum annuum L.)

\begin{abstract}
Large red chili pepper (Capsicum annuum L.) has a fairly complete nutrition and economic value. The supply of large red chili in the country is considered low compared to its demand, that's why we need to increase its production. Increasing production can be done by fertilizing using natural fertilizers is coconut water (Cocos nucifera L.) and administration of Growth Regulatory Substances (ZPT) is atonik. The purpose of this research is to determine the effect of coconut water and atonic to the growth of large red chilli pepper sprouts determine which consentration of coconut water and atonic that has the most effective effect to the growth of large chilli pepper. This research was conducted in October - November 2019 at the Botany Laboratory, Department of Biology, Faculty of Mathematics and Science, University of Lampung. This research was carried out using a $2 \times 3$
\end{abstract}


factorial design using young coconut water (a) with 3 levels of concentration ie $0 \% \mathrm{v} / \mathrm{v}\left(\mathrm{a}_{1}\right), 25 \% \mathrm{v}$ / v $\left(\mathrm{a}_{2}\right)$ and $50 \% \mathrm{v} / \mathrm{v}\left(\mathrm{a}_{3}\right)$ and atonic solution ( b) with 2 concentrations, namely $0 \% \mathrm{v} / \mathrm{v}\left(\mathrm{b}_{1}\right)$ and $10 \% \mathrm{v} / \mathrm{v}\left(\mathrm{b}_{2}\right)$. Data analysis is the data homogeneous first with the Levene test at $5 \%$ significance level. Data analysis using analysis of variance (Analysis Of Variance) $a=5 \%$. If the interaction between the two factors is real, then proceed with the determination of the simple effect of coconut water at each level of atonic concentration with the $\mathrm{F}$ test at $5 \%$ significance level. The results of this research shows that the use of atonic and coconut water effects the growth of large red chili plants, and the most effective concentration to the growth of large red chilli pepper plants is the combination of $0 \%$ coconut water $+10 \%$ atonic.

Keywords: coconut water, atonik, large red chili pepper (Capsicum annuum L.)

\section{PENDAHULUAN}

Cabai merah besar (Capsicum annuum L.) merupakan salah satu komoditas hortikultura yang penting di Indonesia. Cabai merah besar memiliki kandungan gizi yang cukup lengkap juga memiliki nilai ekonomis tinggi. Cabai merah besar dan kebudayaan masyarakat Indonesia hampir tidak dapat dipisahkan, terutama dalam hal masak-memasak. Hampir dalam semua sajian hidangan terdapat masakan yang mengandung cabai merah besar, meskipun hanya sedikit (Warisno \& Dahana, 2018). Berdasarkan data Kementrian Pertanian (2019) produksi cabai merah besar pada tahun 2016 sebesar 1,04 juta ton, tahun 2017 meningkat menjadi 1,21 juta ton dan 1,12 juta ton tahun 2019. Konsumsi cabai merah diperkirakan terus mengalami peningkatan dari tahun 2016-2019. Pada tahun 2016 jumlah konsumsi sebesar 1,55 (kg/kapita), tahun 2017 jumlah konsumsi menjadi 1,56 (kg/kapita) dan tahun 2019 menjadi 1,58 (kg/kapita). Ketersediaan cabai merah besar dalam negeri masih rendah dibandingkan kebutuhan akan cabai yang tinggi, dengan demikian produksi cabai merah besar di Indonesia perlu ditingkatkan. Peningkatan produksi bisa dilakukan dengan pemupukan menggunakan pupuk alami dan pemberian Zat Pengatur Tumbuh (ZPT) (Statistik, 2018).

Salah satu pupuk alami yang dapat meningkatkan pertumbuhan vegetatif tanaman adalah air kelapa (Cocos nucifera L.) dan pemberian ZPT sebagai pengatur tumbuh seperti atonik. Air kelapa (Cocos nucifera L.) sangat mudah ditemui dan murah harganya, dalam air kelapa mengandung zat atau bahan-bahan seperti karbohidrat, vitamin, mineral, protein, gula, asam amino, dan fitohormon yang memiliki efek signifikan terhadap pertumbuhan tanaman, serta zat tumbuh auksin, sitokinin dan giberelin yang berfungsi sebagai pemicu terjadinya proliferasi jaringan, metabolisme dan respirasi sel. Air kelapa juga mengandung ZPT yang digunakan dalam kultur jaringan dapat meningkatkan inisiasi kalus dan perkembangan akar (Winarto \& da Silva, 2015). Dalam penelitian Siahaan, (2004) memperlihatkan bahwa penggunaan air kelapa muda sebagai ZPT dapat meningkatkan pertumbuhan dan produksi cabai merah. Penambahan ZPT dapat mengontrol perkembangan zat meristem sehingga akan berpengaruh pada pemanjangan sel, dengan menggunakan kosentrasi yang sesuai dapat membantu pertumbuhan tanaman, karena ZPT merupakan salah satu komponen yang dibutuhkan pada proses pertumbuhan tanaman selain karbohidrat dan protein, yaitu salah satunya adalah atonik yang berfungsi memacu pertumbuhan tanaman (Rachmawati et al., 2018). Penambahan zat-zat yang berasal dari atonik sangat dibutuhkan oleh tanaman yaitu untuk membantu mengaktifkan kerja enzim (Azwar et al., 2018). Sementara Hidayanto et al., (2014) mengatakan bahwa senyawa nitro aromatic $\left(\mathrm{C}_{6} \mathrm{H} 4 \mathrm{NaNO} 2\right)$ pada atonik dapat 
meningkatkan perkembangan akar dan memacu pertumbuhan tunas. Senyawa dinitrophenol pada atonik dapat meningkatkan penyerapan hara dan memacu keluarnya kuncup.

\section{BAHAN DAN METODE}

Penelitian ini dilakukan di laboratorium Botani Fakultas Matematika dan Ilmu Pengetahuan Alam Universitas Lampung pada Oktober-November 2019. 150 biji cabai dipilih yang memiliki viabilitas yang tinggi, bersih, tidak cacat, tidak terkena jamur dan bakteri. Seleksi biji dilakukan dengan perendaman biji di dalam air hangat selama 5 menit. Biji dipilih yang bersih dan tenggelam di dalam air, hal tersebut dilakukan untuk memilih biji yang bernas (memiliki cadangan makanan yang penuh). Dari 150 biji dipilih sebanyak 120 biji yang bernas dan tenggelam. Kemudian masing-masing satuan percobaan ditanami sebanyak 4 biji di dalam polybag dengan ukuran $25 \times 25$ yang sudah diisi tanah sebanyak $1 \mathrm{~kg}$ dengan isian $3 / 4$ bagian. Disiram setiap pagi dan sore dan diamati setiap hari dan di catat pertumbuhannya selama seminggu sekali selama 4 minggu.

Rancangan percobaan yang digunakan dalam penelitian ini adalah Rancangan Faktorial $2 \times 3$, Parameter yang diamati adalah tinggi tanaman, berat kering, kadar air relatif, dan kandungan klorofil. Data yang diperoleh selanjutnya dihomogenkan dahulu dengan uji Levene pada taraf nyata 5\%. Analisis data menggunakan analisis ragam (Analysis Of Variance) $a=5 \%$. Jika interaksi kedua faktor (Faktor A dan B) tidak nyata maka ditentukan main effect dengan uji Tukey pada taraf nyata 5\%. Jika interaksi kedua faktor nyata maka dilanjutkan dengan penentuan simple effect air kelapa pada setiap taraf konsentrasi atonik dengan uji $\mathrm{F}$ pada taraf nyata $5 \%$.

\section{HASIL}

\section{A. Tinggi Tanaman}

Uji Levene pada taraf nyata 5\% menunjukkan bahwa ragam sampel adalah homogen untuk minggu $4(p>0,05)$. Analisis ragam pada taraf nyata 5\% menunjukkan bahwa interaksi antara air kelapa dan atonik berpengaruh nyata terhadap tinggi tanaman cabai merah besar.

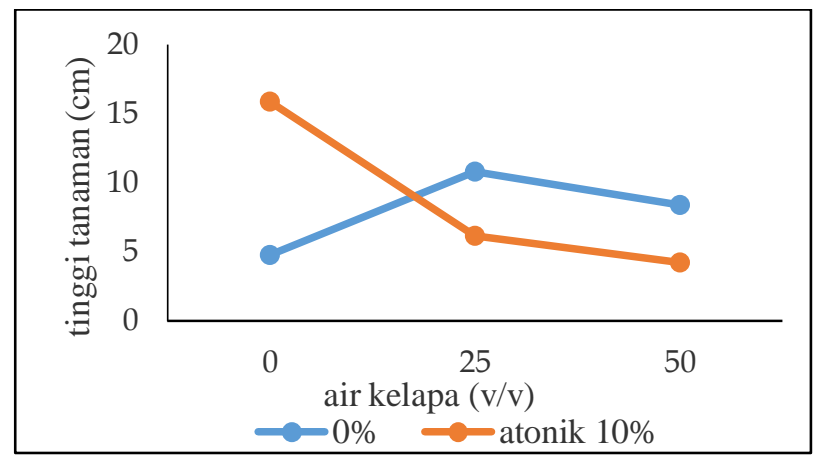

Gambar 1. Kurva Interaksi Antara Air Kelapa dan Atonik Terhadap Tinggi Tanaman Cabai Merah Besar 4 Minggu Setelah Perlakuan.

Pada Gambar 1 menunjukkan bahwa terjadi penurunan antara atonik 10\% + air kelapa 0\% dengan atonik $10 \%$ + air kelapa 25\% secara signifikan, lalu antara atonik $10 \%$ + air kelapa $25 \%$ dengan atonik $10 \%$ + air kelapa 50\% terjadi penurunan juga tetapi tidak signifikan. Lalu pada atonik $0 \%+$ air kelapa $0 \%$ dengan atonik $0 \%+$ air kelapa $25 \%$ terjadi kenaikan secara 
signifikan, kemudian pada atonik $0 \%+$ air kelapa $25 \%$ dengan atonik $0 \%+$ air kelapa $50 \%$ terjadi penurunan dengan hasil yang tidak signifikan.

\section{B. Berat Segar}

Uji Levene pada taraf nyata 5\% menunjukkan bahwa menunjukkan bahwa ragam sampel adalah homogen untuk berat segar $(p>0,05)$. Analisis ragam pada taraf nyata $5 \%$ menunjukkan bahwa interaksi antara air kelapa dan atonik berpengaruh nyata terhadap berat segar tanaman cabai merah besar $(\mathrm{p}<0,05)$.

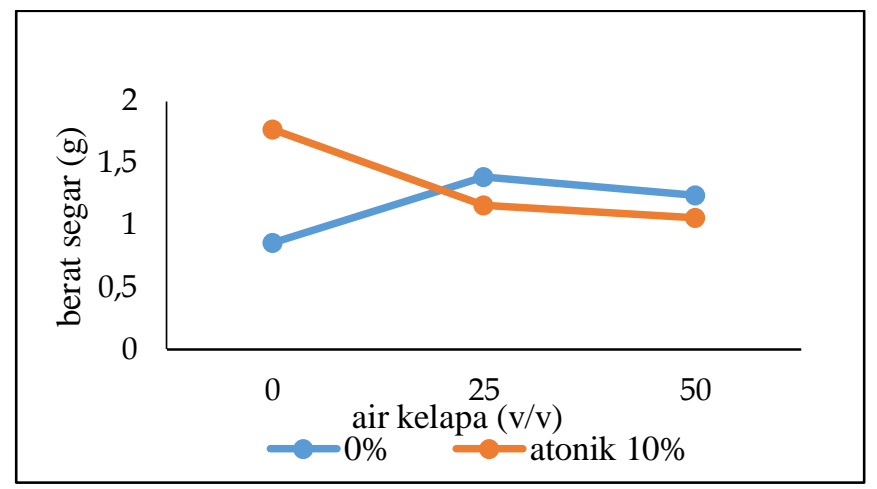

Gambar 2. Kurva Interaksi Antara Air Kelapa dan Atonik Terhadap Berat Segar Tanaman Cabai Merah Besar 4 Minggu Setelah Perlakuan.

Pada Gambar 2 menunjukkan bahwa interaksi antara air kelapa 0\% + atonik 10\% dengan air kelapa $0 \%+$ atonik $0 \%$ hasil yang didapat yaitu signifikan, lalu pada air kelapa $25 \%+$ atonik $10 \%$ dengan air kelapa $25 \%+$ atonik $0 \%$ hasilnya yaitu tidak signifkan, pada air kelapa $50 \%+$ atonik $10 \%$ dengan air kelapa $50 \%+$ atonik $0 \%$ mendapatkan hasil yang tidak signifikan terhadap berat segar tanaman cabai merah besar.

\section{Berat Kering}

Uji Levene pada taraf nyata 5\% menunjukkan bahwa ragam sampel adalah homogen untuk berat kering $(p>0,05)$ Analisis ragam pada taraf nyata $5 \%$ menunjukkan bahwa interaksi antara air kelapa dan atonik berpengaruh nyata terhadap berat kering tanaman cabai merah besar $(\mathrm{p}<0,05)$.

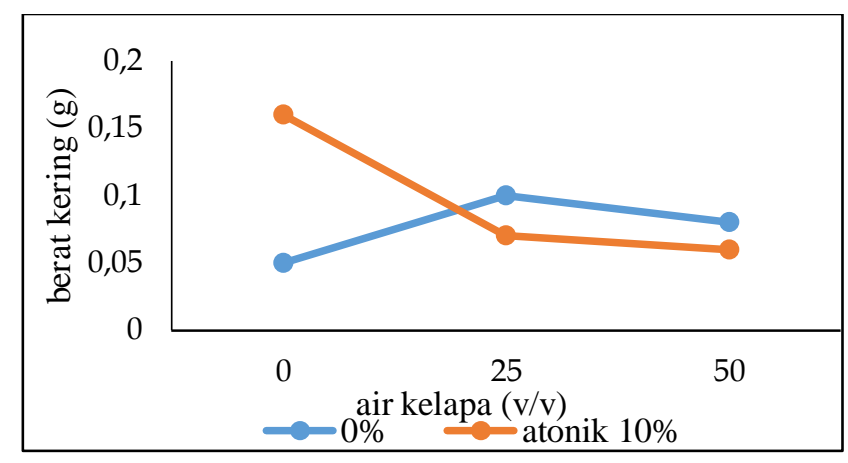

Gambar 3. Kurva Interaksi Antara Air Kelapa dan Atonik Terhadap Berat kering Tanaman Cabai Merah Besar 4 Minggu Setelah Perlakuan. 
Pada Gambar 3 menunjukkan bahwa interaksi antara air kelapa 0\% + atonik 10\% dengan air kelapa $0 \%$ + atonik $0 \%$ hasil yang didapat yaitu signifikan, lalu pada air kelapa $25 \%+$ atonik $10 \%$ dengan air kelapa $25 \%+$ atonik $0 \%$ hasilnya yaitu tidak signifkan, pada air kelapa 50\% + atonik $10 \%$ dengan air kelapa $50 \%+$ atonik $0 \%$ mendapatkan hasil yang tidak signifikan terhadap berat kering tanaman cabai merah besar.

\section{Kadar Air Relatif}

Uji Levene pada taraf nyata 5\% menunjukkan bahwa ragam sampel adalah homogen untuk minggu $4(p>0,05)$. Analisis ragam pada taraf nyata 5\% menunjukkan bahwa interaksi antara air kelapa dan atonik tidak berpengaruh nyata terhadap kadar air relatif tanaman cabai merah besar $(\mathrm{p}<0,05)$.

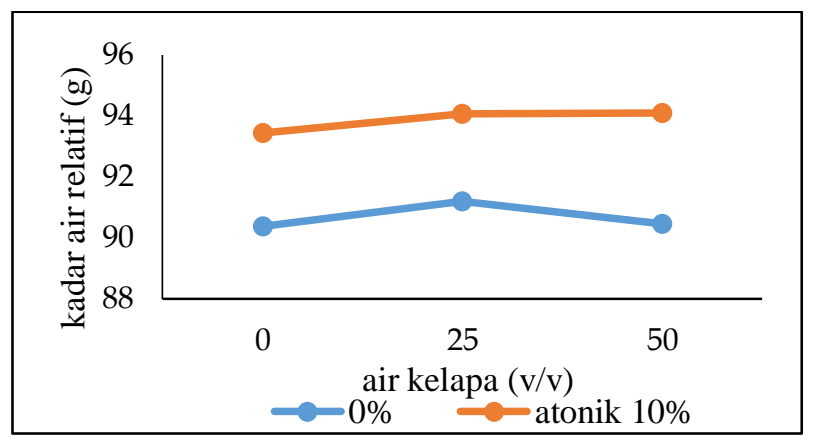

Gambar 4. Kurva Interaksi Antara Air Kelapa dan Atonik Terhadap Kadar Air Relatif Tanaman Cabai Merah Besar 4 Minggu Setelah Perlakuan.

Pada Gambar 4 menunjukkan bahwa tidak adanya interaksi antara air kelapa dan atonik sehingga tidak signifikan pada kadar air relatif.

\section{E. Klorofil a}

Uji Levene pada taraf nyata 5\% menunjukkan bahwa ragam sampel adalah homogen untuk klorofil a $(p>0,05)$. Analisis ragam pada taraf nyata 5\% menunjukkan bahwa interaksi antara air kelapa dan atonik berpengaruh nyata terhadap klorofil a tanaman cabai merah besar $(\mathrm{p}<0,05)$.

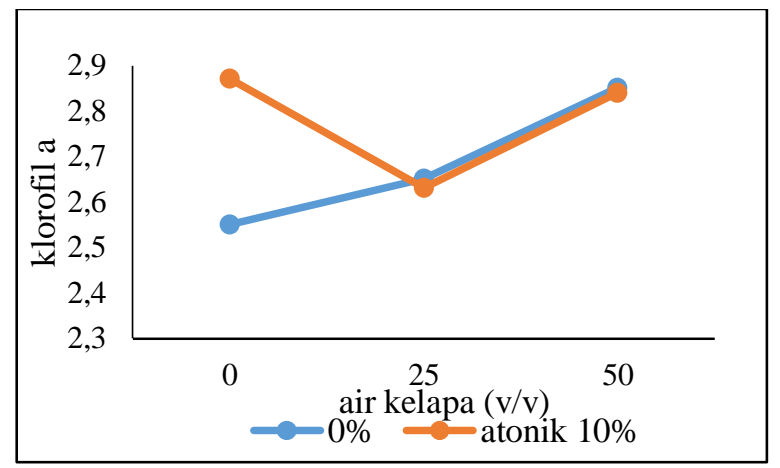

Gambar 5. Kurva Interaksi Antara Air Kelapa dan Atonik Terhadap Klorofil a Tanaman Cabai Merah Besar 4 Minggu Setelah Perlakuan. 
Pada Gambar 5 menunjukkan bahwa interaksi antara air kelapa 0\% + atonik 10\% dengan air kelapa $0 \%+$ atonik $0 \%$ hasil yang didapat yaitu signifikan, lalu pada air kelapa $25 \%+$ atonik $10 \%$ dengan air kelapa $25 \%$ + atonik $0 \%$ hasilnya yaitu tidak signifkan, begitu juga pada air kelapa $50 \%$ + atonik $10 \%$ dengan air kelapa 50\% + atonik $0 \%$ mendapatkan hasil yang tidak signifikan terhadap klorofil a tanaman cabai merah besar.

\section{F. Klorofil b}

Uji Levene pada taraf nyata 5\% menunjukkan bahwa ragam sampel adalah homogen untuk klorofil $\mathrm{b} p>0.05$ ) Analisis ragam pada taraf nyata 5\% menunjukkan bahwa interaksi antara air kelapa dan atonik berpengaruh nyata terhadap klorofil $b$ tanaman cabai merah besar $(p<0.05)$.

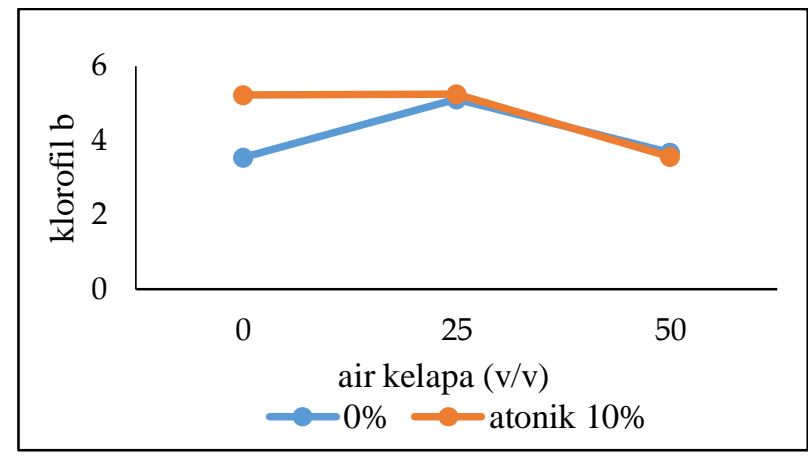

Gambar 6. Kurva Interaksi Antara Air Kelapa dan Atonik Terhadap Klorofil b Tanaman Cabai Merah Besar 4 Minggu Setelah Perlakuan.

Pada Gambar 6 menunjukkan bahwa interaksi antara air kelapa 0\% + atonik 10\% dengan air kelapa $0 \%$ + atonik $0 \%$ hasil yang didapat yaitu signifikan, lalu pada air kelapa $25 \%+$ atonik $10 \%$ dengan air kelapa $25 \%$ + atonik $0 \%$ hasilnya yaitu tidak signifkan, begitu juga pada air kelapa 50\% + atonik 10\% dengan air kelapa 50\% + atonik $0 \%$ mendapatkan hasil yang tidak signifikan terhadap klorofil $\mathrm{b}$ tanaman cabai merah besar.

\section{G.Klorofil Total}

Uji Levene pada taraf nyata 5\% menunjukkan bahwa ragam sampel adalah homogen untuk klorofil total $(p>0.05)$ Analisis ragam pada taraf nyata 5\% menunjukkan interaksi antara air kelapa dan atonik juga berpengaruh nyata terhadap klorofil $\mathrm{b}$ tanaman cabai merah besar $(\mathrm{p}<0.05)$. 
Fassya, H.M.,Handayani, T.T., Wahyuningsih, S., \& Mahfut. 2020. Air kelapa, atonik, cabai merah besar

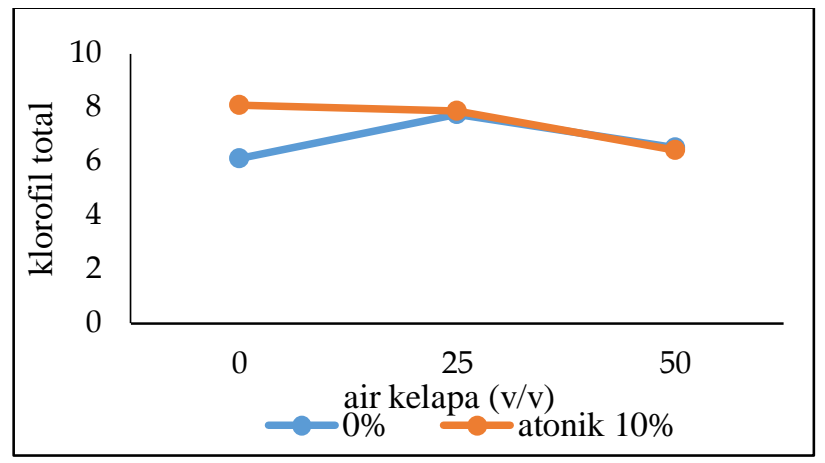

Gambar 7. Kurva Interaksi Antara Air Kelapa dan Atonik Terhadap Klorofil total Tanaman Cabai Merah Besar 4 Minggu Setelah Perlakuan.

Pada Gambar 7 menunjukkan bahwa interaksi antara air kelapa 0\% + atonik 10\% dengan air kelapa $0 \%+$ atonik $0 \%$ hasil yang didapat yaitu signifikan, lalu pada air kelapa $25 \%+$ atonik $10 \%$ dengan air kelapa $25 \%$ + atonik $0 \%$ hasilnya yaitu tidak signifkan, begitu juga pada air kelapa $50 \%$ + atonik $10 \%$ dengan air kelapa 50\% + atonik $0 \%$ mendapatkan hasil yang tidak signifikan terhadap klorofil total tanaman cabai merah besar.

\section{PEMBAHASAN}

\section{A. Tinggi Tanaman}

Hasil yang paling baik dan efektif untuk tinggi tanaman ada pada konsentrasi air kelapa $0 \%+$ atonik $10 \%$. Hal tersebut diduga karena pemberian air kelapa $0 \%+$ atonik $10 \%$ sudah dapat mencukupi kebutuhan unsur hara pada tanaman cabai merah besar. Menurut Górnik et al., (2007) atonik efektif mempercepat perkembangan sel, meningkatkan perkecambahan benih, menambah kekuatan tanaman, jumlah bunga, dan akhirnya meningkatkan produksi tanaman, sehingga mendukung proses metabolisme tanaman dan memberikan pengaruh yang baik terhadap pertumbuhan tinggi tanaman cabai merah besar. Menurut Lingga \& Marsono, (2004), dengan bantuan zat pengatur tumbuh tanaman akan dapat menyerap hara melalui daun dan ditranslokasikan ke seluruh bagian tubuh tumbuhan.

Pada konsentrasi air kelapa 25\% dan air kelapa 50\%, ditambah dengan atonik $10 \%$ maupun atonik $0 \%$, sebenarnya sudah mampu memacu tinggi tanaman cabai merah besar, namun belum mampu mempercepat tinggi tanaman. Hal ini sesuai dengan pendapat Darlina et al., (2016), pupuk alami bermanfaat untuk meningkatkan kandungan unsur hara yang dibutuhkan tanaman, meningkatkan produktivitas tanaman, merangsang pertumbuhan akar, batang, daun, menggemburkan dan menyuburkan tanah.

\section{B. Berat Segar}

Konsentrasi yang paling efektif pada semua konsentrasi yaitu ada pada konsentrasi air kelapa $0 \%+$ atonik $10 \%$. Hidayanto et al., (2014) menginformasikan bahwa senyawa nitro aromatic pada atonik dapat meningkatkan perkembangan akar dan memacu pertumbuhan tunas. Senyawa dinitrophenol pada atonik dapat meningkatkan penyerapan hara dan memacu keluarnya kuncup, sehingga dapat memberikan hasil yang baik terhadap berat segar tanaman cabai merah besar. 
Pada konsentrasi air kelapa 25\% + atonik $10 \%$ dengan air kelapa $25 \%+$ atonik $0 \%$ maupun air kelapa $50 \%+$ atonik $10 \%$ dengan air kelapa 50\% + atonik $0 \%$. Hasil yang paling baik diantaranya yaitu ada pada konsentrasi air kelapa 25\% dan air kelapa 50\% dengan konsentrasi atonik 0\%. Menurut Winarto \& da Silva, (2015) air kelapa mengandung karbohidrat, vitamin, protein, asam amino serta hormon auksin, sitokinin dan giberellin yang berfungsi sebagai pemicu terjadinya poliferasi jaringan, metabolime dan respirasi sel. Menurut Tiwery, (2014) kandungan auksin dan sitokinin yang terdapat dalam air kelapa mempunyai peranan penting dalam proses pembelahan sel sehingga membantu pembentukan tunas. Sitokinin akan memacu sel untuk membelah secara cepat, sedangkan auksin akan memacu sel untuk memanjang. Pembelahan sel yang dipacu oleh sitokinin dan pembesaran sel yang dipacu oleh auksin menyebabkan terjadinya pertumbuhan. Sel yang membelah akan mengalami pembentangan yang selanjutnya akan mengalami deferensiasi dan terjadinya spesialisasi. Menurut Sri Aryanti \& Izzati, (2012), pertambahan berat dipengaruhi oleh adanya proses pemanjangan sel yang diikuti dengan pembesaran sel. Sehingga dapat memberikan hasil yang baik terhadap berat segar tanaman cabai merah besar. Gardner et al., (1991) menyatakan bahwa pertumbuhan adalah pembelahan sel (peningkatan jumlah) dan pembesaran sel (peningkatan ukuran) yang terakumulasi pada berat basah dan berat kering tanaman.

\section{Berat Kering}

Konsentrasi yang paling efektif yaitu ada pada konsentrasi air kelapa $0 \%+$ atonik $10 \%$. Senyawa nitro aromatic pada atonik dapat meningkatkan perkembangan akar dan memacu pertumbuhan tunas. Peningkatan penyerapan hara dan memacu keluarnya kuncup bisa disebabkan oleh senyawa dinitrophenol yang terkandung didalam atonik (Hidayanto et al., 2003). Penambahan zat-zat yang berasal dari atonik sangat dibutuhkan oleh tanaman yaitu untuk membantu mengaktifkan kerja enzim, tanpa adanya enzim maka proses metabolisme akan berlangsung lambat.

Pada konsentrasi air kelapa 50\% + atonik 10\% diduga memiliki komposisi yang cukup banyak sehingga kurang efektif dalam mempercepat pertumbuhan tanaman cabai merah besar. Hal ini sesuai dengan pendapat Supriyanto \& Prakarsa, (2011) yang menginfromasikan bahwa konsentrasi yang terlalu tinggi akan menghambat pertumbuhan, meracuni bahkan mematikan tanaman. Khair et al., (2015) juga mengemukakan bahwa ZPT akan efektif pada konsentrasi tertentu. Jika konsentrasi yang digunakan terlalu tinggi maka akan dapat merusak tanaman, menghambat pertumbuhan dan perkembangan tunas, menyebabkan penguningan dan gugur daun, penghitaman batang dan akhirnya menyebabkan kematian, sedangkan bila konsentrasi yang digunakan di bawah optimum maka ZPT tersebut tidak efektif. Menurut Nana \& Salamah, (2014) hormon auksin akan meningkatkan pertumbuhan sampai mencapai konsentrasi yang optimal. Apabila konsentrasi yang diberikan melebihi konsentrasi yang optimal, maka akan mengganggu metabolisme dan perkembangan tumbuhan sehingga menurunkan pertumbuhan.

\section{Kadar Air Relatif}

Kadar air relatif tidak terdapat interaksi pada semua konsentrasi, hal ini diduga karena molekul air dalam tanah terikat dalam atonik maupun air kelapa, tanaman dengan konsentrasi yang tinggi menggunakan air kelapa $25 \%$, dan $50 \%$ yang ditambah dengan atonik $10 \%$ yang banyak untuk proses fotosintesis dan metabolisme yang aktif sehingga kadar air yang terkandung dalam tanaman harus dalam jumlah banyak, namun pada konsentrasi yang 
rendah seperti atonik $0 \%$ dan atonik $10 \%$ yang tidak memberikan akifitas yang tinggi, sehingga air yang tertinggal juga banyak. Diduga tanaman yang diberi konsentrasi atonik $0 \%$ dan atonik $10 \%$ yang tidak ditambahkan air kelapa metabolismenya tidak aktif sehingga transpirasi memicu pemasukan air pada tanaman dengan konsentrasi rendah. Ketersediaan air yang cukup bagi tanaman akan membantu tanaman untuk tumbuh lebih optimal baik dalam proses pembentukan metabolisme, fotosintesis, respirasi, dan lain-lain (Sarief, 1986).

\section{E. Klorofil $a, b$ dan Total}

Interaksi klorofil a, b dan total pada konsentrasi air kelapa $0 \%+$ atonik $10 \%$ menunjukkan hasil yang signifikan (berbeda nyata) dengan konsentrasi air kelapa $0 \%+$ atonik $0 \%$, hal tersebut diduga karena pemberian air kelapa $0 \%+$ atonik $10 \%$ telah aktif merangsang seluruh jaringan tanaman cabai merah besar untuk melakukan fotosintesis sehingga klorofil yang diserap banyak. Menurut Rachmawati et al., (2018) mengatakan bahwa pemberian atonik dapat mencukupi kebutuhan hara pada tanaman, merangsang pertumbuhan akar, mengaktifkan penyerapan unsur hara, mengaktifkan enzim. Menurut Mukhlis et al., (2011) menginformasikan bahwa banyaknya jumlah daun yang terbentuk, maka kemampuan daun dalam menerima cahaya untuk proses fotosintesis menjadi lebih besar dalam menghasilkan karbohidrat sehingga mempengaruhi besar dan berat tanaman tersebut. Pada konsentrasi air kelapa $25 \%$ dan $50 \%$ yang ditambah dengan atonik $10 \%$ diduga memiliki komposisi yang cukup banyak sehingga kurang efektif dalam mempercepat pertumbuhan tanaman cabai merah besar. Hal ini sejalan yang dikemukakan oleh Hartmann \& Kester, (1990) bahwa ZPT hanya efektif pada konsentrasi tertentu. Konsentrasi yang terlalu tinggi akan menghambat pertumbuhan, meracuni bahkan mematikan tanaman (Supriyanto \& Prakarsa, 2011). Salisbury \& Ross, (1995), menyatakan ZPT merupakan suatu zat pendorong pertumbuhan apabila diberikan dalam konsentrasi yang tepat. Sebaliknya bila diberikan dalam konsentrasi yang tinggi dari yang dibutuhkan tanaman maka akan menghambat dan menyebabkan kurang aktifnya proses metabolisme tanaman.

\section{KESIMPULAN}

Hasil penelitian yang telah dilakukan dapat disimpulkan bahwa penambahan air kelapa dan atonik mempengaruhi pertumbuhan tanaman cabai merah besar, dan konsentrasi yang efektif untuk pertumbuhan tanaman cabai merah besar yaitu kombinasi antara air kelapa $0 \%$ dan atonik $10 \%$.

\section{DAFTAR PUSTAKA}

Azwar, Pasigai, M., \& Lasmini, S. (2018). Pengaruh Konsentrasi Atonik terhadap Pertumbuhan dan Hasil Bawang Merah (Allium cepa var aggregatum L.) Varietas Lembah Palu. Agrotekbis, 6(4), 444451.

Darlina, Hasanuddin, \& Rahmatan, H. (2016). Pengaruh penyiraman air kelapa (Cocos nucifera L.) terhadap pertumbuhan vegetatif lada (Piper nigrum L.). Jurnal Ilmiah Mahasiswa Pendidikan Biologi, 1(1), 20-28. http://www.jim.unsyiah.ac.id/pendidikan-biologi/article/view/309

Gardner, F. P., Pearce, R. B., \& Mitchell, R. L. (1991). Physiology of Crop Plants (H. Susilo (ed.); Terjemahan). Universitas Indonesia Press.

Górnik, K., Grzesik, M., \& Mika, A. (2007). Improvement of grapevines rooting and growth of plants 


\section{TECHNO: Vol. 09 (01) Mei 2020}

under stress conditions by Asahi SL. Folia Hortic, 19(2), 57-67.

Hartmann, H. T., \& Kester, D. E. (1990). Hartmann and Kester's plant propagation: principles and practice. Prentice Hall.

Hidayanto, M., Nurjanah, S., \& Yosita, F. (2014). Pengaruh Panjang Stek Akar dan Konsentrasi Natriumnitrofenol terhadap Pertumbuhan Stek Akar Sukun (Artocarpus communis F.). Jurnal Pengkajian Dan Pengembangan Teknologi Pertanian, 6(2), 154-160.

Kementerian Pertanian. 2019. Produksi dan Konsumsi Cabai Tahun 2019. Badan Pengkajian dan Pengembangan Perdagangan Kementerian Perdagangan Republik Indonesia. Jakarta

Khair, H., \& Hamdani, Z. R. (2015). Pengaruh Konsentrasi Ekstrak Bawang Merah dan Air Kelapa Terhadap Pertumbuhan Stek Tanaman Melati Putih (Jasminum sambac L.). AGRIUM: Jurnal Ilmu Pertanian, 18(2).

Lingga, P., \& Marsono. (2004). Petunjuk Penggunaan Pupuk. Penebar Swadaya.

Mukhlis, M., Purwaningsih, P., \& Anggorowati, D. (2011). Pengaruh Berbagai Jenis Mikroorganisme Lokal (Mol) Terhadap Pertumbuhan Dan Hasil Bawang Merah Pada Tanah Aluvial. Jurnal Sains Mahasiswa Pertanian Untan, 1(1).

Nana, S. A., \& Salamah, Z. (2014). Pertumbuhan Tanaman Bawang Merah (Allium cepa L.) dengan Penyiraman Air Kelapa (Cocos nucifera L.) Sebagai Sumber Belajar Biologi SMA Kelas XII. Jupemasi-Pbio, 1(1), 82-86.

Rachmawati, D. L., Roviq, M., \& Islami, T. (2018). Komposisi Atonik dan Air Kelapa pada Pertumbuhan Bud Chips Tebu (Saccharum officinarum L.). Jurnal Produksi Tanaman, 5(5).

Salisbury, B. F., \& Ross, D. W. . (1995). Fisiologi Tumbuhan. In ITB Bandung. ITB Press.

Sarief, E. S. (1986). Kesuburan dan Pemupukan Tanah Pertanian. In Pustaka Buana. Bandung (Vol. 182).

Siahaan, E. (2004). Pengaruh Kosentrasi Air Kelapa Muda Terhadap Pertumbuhan Produksi Cabai Merah (Capsicum annum L.).[Skripsi]. In Fakultas Pertanian. Universitas Riau.

Sri Aryanti, W., \& Izzati, M. (2012). Kinerja Zat Pemacu Pertumbuahan Dari Cairan Rumput Laut Sargassum Polycistum Dalam Meningkatkan Pertumbuhan Kedelai (Glycine Max L Merril). Anatomi Fisiologi, 17(2), 41-47.

Statistik, B. P. (2018). Produksi Cabai Besar, Cabai Rawit, dan Bawang Merah. In Berita Resmi Statistik Provinsi Jawa Barat. Tersedia online pada: ww. bps. go. id/new/website/brs_ind/brsInd20150803144409.(diakses 2 April 2018).

Supriyanto, \& Prakarsa, K. . (2011). Pengaruh Zat Pengatur Tumbuh Rootone-F terhadap Pertumbuhan Stek Duabanga moluccana. Blume. Jurnal Silvikultur Tropika, 3(1), 59-65.

Tiwery, R. R. (2014). Pengaruh Penggunaan Air Kelapa (Cocos nucifera) terhadap Pertumbuhan Tanaman Sawi (Brassica juncea L.). BIOPENDIX: Jurnal Biologi, Pendidikan Dan Terapan, 1(1), 86-94.

Warisno, S., \& Dahana, K. (2018). Peluang Usaha dan Budi Daya Cabai. Gramedia Pustaka Utama.

Winarto, B., \& da Silva, J. A. T. (2015). Use of coconut water and fertilizer for in vitro proliferation and plantlet production of Dendrobium 'Gradita 31.' In Vitro Cellular \& Developmental Biology-Plant, 51(3), 303-314. 